\title{
Espiritualidade ateia: um ensaio saramaguiano
}

\author{
Karina Masci Silveira Raydan*
}

http://lattes.cnpq.br/9111344772132179

Enviado em: 17/09/2018

Aceito em: 18/11/2018

Resumo: A literatura de José Saramago é envolta em polêmicas acerca das provocações e críticas religiosas expressas pelo autor. Em suas obras podemos identificar uma complexidade psíquica das personagens e questionamentos sociais, culturais, religiosos e existenciais. $\mathrm{Na}$ trama de Ensaio sobre a cegueira (ESC) podemos pensar em uma metáfora que remete à cegueira social e em reflexões, virtudes e posicionamentos humanos que apontam para a superação desse mal. Percebemos que a literatura de Saramago é permeada de apontamentos para a construção de valores humanos, revelando expressões sobre uma espiritualidade ateia. Embasados nas contribuições teóricas de André Comte-Sponville no que tange a espiritualidade ateia, objetivamos a construção de pontes entre esse fenômeno religioso e a obra saramaguiana. Para tanto, nos aportaremos, metodologicamente, nas contribuições do campo da teopoética.

Palavras-chave: Saramago; Espiritualidade ateia; Comte-Sponville; Teopoética.

Abstract: José Saramago's literature is embroiled in polemics about the provocations and religious criticisms expressed by the author. In his works we can identify a psychic complexity of the characters and social, cultural, religious and existential questions. In the novel Blindness we can think of a metaphor that refers to social blindness and in reflections, virtues and human positions that point to overcoming this evil. We realize that the literature of Saramago is permeated with notes for the construction of human values, revealing expressions about an atheistic spirituality. Based on the theoretical contributions of André Comte-Sponville in regard to atheistic spirituality, we aim to build bridges between this religious phenomenon and the Saramaguian novel. To do so, we will contribute methodologically to the contributions of the field of theopoetics.

Keywords: Saramago; Atheist spirituality; Comte-Sponville; Theopoetics.

\section{Introdução}

Diante das mudanças contemporâneas acerca do religioso, novas formas de espiritualidade têm se despontado, sendo tema que tem solicitado reflexões por parte das ciências da religião. Porém, ainda há muito o que se percorrer nesse sentido, sobretudo quando se trata das espiritualidades não religiosas, e mais especificamente, sobre as espiritualidades laicas, ateias e agnósticas. É sabido que as artes em geral costumam expressar, direta ou indiretamente, processos de subjetivação que perpassam a época e constituem o mundoda-vida ${ }^{1}$ de dados sujeitos, dadas comunidades ou dadas sociedades. Compreendo que a

\footnotetext{
* Mestranda pelo Programa de Pós-Graduação em Ciências da Religião pela PUC Minas, bolsista CAPES. Especialista em Arteterapia e em Psicologia Clínica Existencial e Gestáltica. Trabalha como psicóloga na UFMG. E-mail: karinams@yahoo.com.br

${ }^{1} \mathrm{Na}$ perspectiva fenomenológica de Husserl, os fenômenos são entendidos enquanto vivências individuais, mas também circunscritos enquanto culturais e sociais. O conceito de mundo-da-vida para Husserl, segundo Ângela Ales Bello, trata-se da perspectiva subjetiva e intersubjetiva para a compreensão dos fenômenos, uma vez que, para ele, a
} 
literatura de José Saramago possa revelar traços de uma espiritualidade ateia, nossa pesquisa consistiu na identificação e compreensão dessas expressões a partir da narrativa de Ensaio sobre a cegueira (ESC).

A literatura saramaguiana é envolta de polêmicas acerca das críticas religiosas expressas pelo autor. Em suas obras podemos identificar uma complexidade psíquica das personagens e questionamentos sociais, culturais, religiosos e existenciais.

No romance em questão, podemos pensar em uma metáfora que remete à cegueira social e em reflexões, virtudes e posicionamentos humanos que apontam para a superação desse mal, intitulado no romance de mal-branco. Trata-se de uma obra com diversos apontamentos para a construção de valores humanos. Mesmo diante de uma situação caótica, provocada pela epidemia de cegueira Deus não é apontado como possibilidade de salvação, mas, ao contrário, esta se dá na própria dimensão humana. Diante dessas considerações, nos deparamos com o seguinte questionamento: Como e em que medida o texto saramaguiano se apresenta como um possível ensaio para uma espiritualidade ateia?

Para respondermos a este questionamento, nos embasamos metodologicamente nos preceitos do campo investigativo denominado Teopoética. Ressaltamos, desde o princípio, que partimos do pressuposto da independência das áreas: Literatura e Teologia. Portanto, não pretendemos tutelar o texto literário com projeções teológicas. Ao contrário, nossa análise parte exatamente do texto literário. Assim, as análises e as discussões estabelecidas provêm da interação estabelecida entre leitor e obra.

O artigo está dividido em três seções. A primeira traz uma delimitação do campo da Teopoética, indicando preceitos básicos. No segundo momento trazemos uma breve descrição e análise do texto. Por fim, discutirmos os resultados encontrados a partir da interpretação realizada, momento em que inserimos Comte-Sponville e sua proposta de espiritualidade ateia.

\section{Teopoética: delimitando um campo}

Há muito religião e literatura estão, de certa maneira, próximas. Talvez, desde seus princípios. Mas há não tanto tempo assim, estudar essa relação sob o viés acadêmico, ou seja, através de pesquisas e análises sistematizadas, também ganhou forças e tem despertado interesse de áreas diversas do saber, especialmente da teologia, das ciências da religião e da literatura. Assim, um campo interdisciplinar e dialogal que visa compreender essa relação tem se consolidado em tempos mais recentes, como apontam as pesquisas. (BARCELLOS, 2000; CANTARELA, 2014; MANZATTO, 2016).

Demarcando a consolidação desse campo inter-relacional que é a teopoética, Manzatto (1994, 2012a, 2012b, 2016) ressalta a importância dos estudos voltados para o estabelecimento das relações entre religião e literatura. Segundo o teólogo, é relevante um campo em que seja possível realizarmos, a partir de uma obra literária, revelações sobre o humano e a vida real. Isso porque, segundo o pesquisador em teopoética, a arte literária diz do ser humano e do seu mundo, abrindo aos teólogos e cientistas da religião, uma possibilidade de aproximarem-se do conhecimento acerca do humano e de sua existência. Manzatto (2016) destaca que os textos literários podem trazer elementos acerca do sagrado, da transcendência, de comportamentos religiosos, culturais e modos de existência do humano.

Assim, considerando que a literatura pode nos aproximar do mundo em que vivemos,

nossa existência é composta, concomitantemente, por aspectos pessoais e coletivos.

https://periodicos.unifap.br/index.php/letras

Macapá, v. 8, n. 3, $2^{\circ}$ sem., 2018 
Manzatto (1994) destaca o gênero romanesco enquanto aquele que, em seu entendimento, mais pode contribuir na aproximação desse ser humano real. Em sua tese doutoral, o teólogo Márcio Cappelli Aló Lopes, tal como nós propusemos realizar nessa pesquisa, utiliza-se da literatura saramaguiana para realizar pontes entre essa e o universo religioso. Dessa forma, Lopes (2017) endossa o pensamento de Manzatto (1994) sobre o gênero romanesco como lugar privilegiado de reflexão sobre o humano:

O romance é um modo específico de fazer a experiência da realidade. Todavia, a palavra romanesca não deve ser vista só como representação do real, mas também a partir de uma dialética, do seu potencial de transfiguração da vida. Afinal, ela incide no mundo, capta a realidade, mas também propõe a sua subversão. O romance é sim um aparelho de percepção que apreende a vida em toda a sua complexidade e contradição, mas sobretudo uma fonte para a transformação desta. É uma forma de aprofundamento das relações do ser humano com o mundo. Ao mesmo tempo em que é um verdadeiro reduto de todos os problemas em que a sociedade contemporânea traz consigo, ainda se mostra como um verdadeiro lugar de reencontro do ser humano com ele mesmo, com valores coletivos e como horizonte de um futuro (re) humanizado. Ao refletir a vida e projetar sua refração, se revela como uma possibilidade de reinvenção desta. (LOPES, 2017, p. 128-129).

Ressaltamos, do trecho acima destacado, a fala acerca do poder de transformação da realidade que uma obra romanesca possui. Afinal, se um objeto artístico, de modo geral, e uma obra literária, de modo específico, são capazes de tragar a essência da existência e transpô-la em linguagens outras que permitem a subversão e a reconfiguração dessa existência, eles também nos trazem possibilidade de abertura de horizontes na compreensão e mirada existencial. A partir dos pressupostos da Teopoética, passamos, na próxima seção, a desvelar horizontes para compreensão da espiritualidade ateia enquanto fenômeno religioso contemporâneo.

\section{Pontos e vistas: análise interpretativa de Ensaio sobre a cegueira}

A trama de ESC desenvolve-se em uma cidade fictícia, sem nome. Tal como a cidade, Saramago (1995) também não nomeia suas personagens. Assim, elas são identificadas por características físicas, situacionais ou por suas profissões. As personagens principais de ESC são: o primeiro cego, a mulher do primeiro cego, o ladrão de automóveis, o rapazinho estrábico, a rapariga dos óculos escuros, o velho da venda preta, o médico e a mulher do médico. Esta última é a protagonista da história. A história de ESC gira em torno de uma epidemia de cegueira branca, que ficou conhecida como mal-branco no desenvolver da narrativa, e que acometeu toda a cidade, à exceção da mulher do médico.

A análise que realizaremos a seguir, não seguirá a ordem dos acontecimentos do texto. Optamos por realizá-la a partir de categorias de análises, as quais serão fundamentais para a discussão posterior, envolvendo a espiritualidade ateia sponvilliana. Dessa forma, percorreremos, inicialmente, a visão de ser humano, espírito e sociedade apresentadas no texto, o sentido da cegueira branca e a cura da doença.

Ainda nas linhas iniciais, Saramago (1995) aponta traços humanos. Observamos isso quando a narrativa demarca a impaciência dos motoristas que iam atrás do carro do primeiro cego, a curiosidade das pessoas que o cercaram, os diversos palpites e a falta de comunicação, tornando aquele amontoado de palpites um falatório sem sentido e o ato de caridade, feito pelo que mais tarde viemos saber ser um ladrão. Entretanto, foi sua oferta 
de ajuda que fez calar o falatório. Em relação à descrição do primeiro cego, Saramago (1995) evidencia, nesse momento inicial de sua cegueira, uma extrema fragilidade, sentimentos de abandono, medo, desamparo, angústia. Seguindo as linhas narrativas, chegamos ao ponto em que o primeiro cego demonstra desconfiança em relação àquele que o havia ajudado até a porta de sua casa. No segundo capítulo, momento em que o foco narrativo volta-se para o ladrão de automóveis, inicia-se uma reflexão sobre a natureza humana:

[...]o que ele fez não foi mais que obedecer àqueles sentimentos de generosidade e altruísmo que são, como toda gente sabe, duas das melhores características do género humano, podendo ser encontradas até em criminosos bem mais empedernidos que este, simples ladrãozeco de automóveis sem esperança de avanço na carreira, explorado pelos verdadeiros donos do negócio, que esses é que se vão aproveitando de quem é pobre. (SARAMAGO, 1995).

Então, o narrador fala em céticos e não céticos acerca da natureza humana. Estes primeiros, "que são muitos e teimosos, vêm sustentando que se é certo que a ocasião nem sempre faz o ladrão, também é certo que o ajuda muito”. (SARAMAGO, 1995). O narrador, entretanto, parece não se contentar com essa proposta e, sem colocar-se como um cético, diz:

[...]se o cego tivesse aceitado o segundo oferecimento do afinal falso samaritano, naquele derradeiro instante em que a bondade ainda poderia ter prevalecido, [...] quem sabe se o efeito da responsabilidade moral resultante da confiança assim outorgada não teria inibido a tentação criminosa efeito vir ao de cima o que de luminoso e nobre sempre será possível encontrar mesmo nas almas mais perdidas". (SARAMAGO, 1995).

Nesta passagem acima destacada, percebemos que há, além da colocação de características, o estabelecimento de uma relação entre confiança e responsabilidade moral. Junto a isso, faz uma exposição sobre a existência de uma consciência moral, desde tempos remotos:

Uma invenção dos filósofos do Quaternário, quando a alma mal passava ainda de um projecto confuso. Com o andar dos tempos, mais as actividades da convivência e as trocas genéticas, acabámos por meter a consciência na cor do sangue e no sal das lágrimas, e, como se tanto fosse pouco, fizemos dos olhos uma espécie de espelhos virados para dentro, com o resultado, muitas vezes, de mostrarem eles sem reserva o que estámos tratando de negar com a boca. Acresce a isto, que é geral, a circunstância particular de que, em espíritos simples, o remorso causado por um mal feito se confunde frequentemente com medos ancestrais de todo o tipo, donde resulta que o castigo do prevaricador acaba por ser, sem pau nem pedra, duas vezes o merecido. Não será possível, portanto, neste caso, deslindar que parte dos medos e que parte da consciência afligida começaram a apoquentar o ladrão assim que pôs o carro em marcha. (SARAMAGO, 1995).

Desta frase, podemos extrair um elemento que abordaremos em breve: o espírito. Entretanto, não deixa este elemento de fazer parte da composição da noção de ser humano expressa na obra: um ser humano portador de um espírito. Mas nesse momento nos ateremos a outros dois elementos dessa passagem: os olhos como espelhos voltados para dentro e a consciência moral. Os olhos, por toda obra, são destacados no romance. Não são, entretanto, colocados em seu sentido concreto, mas sempre em sentido metafórico, como o caso acima destacado. Então, nos prendendo, por enquanto, a esta passagem apenas, o que 
ele gostaria de indicar com esses olhos sendo espelhos para dentro. Um espelho é um objeto capaz de captar e refletir imagens. Estando ele virado para dentro do próprio ser, o que ele captaria seria o próprio eu. Refletindo, então, a si mesmo, os olhos poderiam expressar o próprio ser? Ou o ego? A alma, o espírito? Com o complemento colocado, de que os olhos denunciam, em algumas situações, o que negamos com as palavras, podemos dizer que a passagem aponta para um ser humano cindido, entre o que há internamente e o que ele expressa, sendo os olhos o indicativo desta desconexão entre ser e dizer. Para fechar o trecho em questão, verificamos que o remorso e os medos ancestrais são colocados como sentimentos que se confundem em "espíritos mais simples". Dessa forma, o transgressor recebe o castigo dobrado: o remorso e o medo. Destarte, apontamos que o ser humano traçado em ESC, possui uma consciência moral e esta seria constituída, além da responsabilidade, também pela culpa e pelo remorso. Estes dois últimos acarretam no castigo. Ademais, como já indicado, nos dá apontamentos sobre a construção do espírito saramaguiano expresso na obra em questão. Estes sentimentos abordados, em princípio, nos parece estarem ligados ao que o autor denominou de espírito.

Com o passar das páginas, sem uma passagem específica que conduza a isso, Saramago (1995) vai desenhando uma imagem de ser humano enquanto um ser construído socialmente. Essa característica é decisiva na narrativa para que possamos compreender a cegueira branca e o ser humano circunscrito nas personagens da história. $\mathrm{O}$ autor vai dando indícios, ao longo do texto, que o ser humano se constitui pelos olhos dos outros. Dessa forma, para existir efetivamente uma pessoa humana, é necessário o olhar do outro, ao mesmo tempo que se faz necessário, também, olhar para o outro. Essa inter-relação entre olhar e ser olhado é fundamental para o desenvolvimento dessa pessoa humana, ao passo que sua falta conduziria à cegueira e sua consequente desumanização, como pode ser verificado no diálogo entre a mulher do médico e seu marido, que segue abaixo:

As imagens não vêem, Engano teu, as imagens vêem com os olhos que as vêem, só agora a cegueira é para todos, Tu continuas a ver, Cada vez irei vendo menos, mesmo que não perca a vista tornar-me-ei mais e mais cega cada dia porque não terei quem me veja. (SARAMAGO, 1995).

Assim, a construção social é outra característica humana revelada pelo texto. No romance, ao chegarem ao manicômio os primeiros cegos depois do médico e de sua esposa, a primeira providência que tomaram foi juntarem-se em uma camarata e apresentarem-se. Estabeleciam relações positivas, como a exemplo da rapariga dos óculos escuros que cuidava do rapazinho estrábico, ou negativas, como o ladrão e o primeiro cego que brigaram pouco depois de terem se reencontrado. Passaram a fazer coisas em grupo, como ir ao banheiro, estabeleceram suas camas como sendo um lugar privado e marcado de cada um. Desenvolveremos mais profundamente esta característica posteriormente, quando levantarmos a questão da "comunidade".

Outro fator expresso ao longo da narrativa, em relação ao desenho de ser humano traçado, é acerca da dualidade entre corpo e espírito, ou físico e psíquico. Essa demarcação fica evidente em diversas passagens. Entretanto, Saramago (1995) não propõe tal dualidade como algo dicotômico, mas como partes interligadas:

Passou-se assim uma hora, aquilo era como uma felicidade, sob a luz suavíssima os próprios rostos encardidos pareciam lavados, brilhavam os olhos dos que não dormiam, o primeiro cego procurou a mão da mulher e apertou-a, por este gesto se observa quanto o descanso do corpo

https://periodicos.unifap.br/index.php/letras Macapá, v. 8, n. 3, $2^{\circ}$ sem., 2018 
pode contribuir para a harmonia dos espíritos. (SARAMAGO, 1995).

A pluralidade representada pelas personagens da obra também nos indicam vasto material acerca da visão de ser humano construída na narrativa. A mulher do médico, através de suas ações, pode ser associada a um ser humano justo, corajoso, atencioso, empático, racional, agregador. A rapariga dos óculos escuros representa a contradição entre moral e caráter. Dizemos isso considerando a sua profissão, prostituta, bem como atitudes de entrega à luxúria, como nas cenas em que ela deitou-se com o ajudante de farmácia, com o velho da venda preta e com o médico. Profissão e atitudes consideradas imorais pela sociedade. Entretanto, demonstrou ser também uma pessoa fiel, cuidadosa, amorosa, maternal. A mulher do primeiro cego apresentava-se, muitas vezes, submissa ao marido e, outras vezes, o enfrentava e demonstrava sua força. O velho da venda preta, por sua vez, talvez pelo simbolismo da idade avançada, carregava traços de sabedoria, humildade, empatia, disposição para ajudar. O médico, além de ser traçado como um ser ponderado, tranquilo e racional, ao longo da narrativa foi colocado como confidente e companheiro da esposa. O primeiro cego mostrou, ao início da narrativa, muita fragilidade. No desenrolar da história, ele vai se construindo como um ser egoísta, em determinados momentos, sem muita empatia e carregado de julgamentos morais. Há ainda o ladrão, que pôde aproveitar-se da fragilidade alheia para subtrair-lhe e abusou da rapariga dos óculos escuros sem sua concessão. Entretanto, diante da dor e sofrimento advindos da ferida infeccionada da perna e do cuidado recebido por todos do grupo, especialmente pela mulher do médico, modificou-se, tornou-se mais humilde e reconheceu seus erros. Por fim, destacamos o grupo composto pelos "malvados", demonstrando um lado cruel, abusivo e desrespeitador do ser humano.

Finalmente, ressaltamos que Saramago (1995) demonstrou, em ESC, um ser humano que se corrompe e se desumaniza diante das adversidades e das necessidades, mas, principalmente, evidenciou a capacidade de o ser humano manter a dignidade humana, mesmo em situações de extremo caos, fome e desorganização. Dessa forma, encontramos na obra em questão uma construção de ser humano dotado de sentimentos plurais e contraditórios, sentimentos estes inseridos no que o autor denominou espírito. É um ser capaz de modificar-se, evoluir positivamente, lutar e enfrentar as adversidades, mas também um ser que pode animalizar-se, ceder aos instintos e caminhar pelas vias da destruição, tal como representado pelos cegos "malvados". É também um ser constituído pelo olhar do outro, bem como pelo olhar o outro e, por fim, é um ser que se desenvolve e vive comunitariamente. Como indicamos, essa descrição de ser humano que evidenciamos na obra nos abre a outras categorias para que possamos compreender melhor esse a visão de ser humano traçada por Saramago (1995): espírito e comunidade. Essas categorias serão analisadas na sequência.

Ao longo da obra em questão, Saramago (1995) utilizou as palavras espírito alma em variados momentos. Vendo a repetição destas palavras ao longo do texto, atrelada ao fato de quase sempre estarem associadas a frases que revelam o ser humano saramaguiano e a cegueira branca, percebemos a importância de compreender o sentido destes termos. A primeira questão a se verificar é se alma e espírito são termos utilizados como sinônimos no texto.

Nas passagens em que o termo alma foi usado, seu sentido referia-se a algo interior, o $\mathrm{Eu}$, a personalidade, o caráter, enfim, o sujeito. A alma, em nosso entendimento, seria aquilo que representa a construção de cada ser humano, carregado de seus sentimentos, desejos, medos, angústias, amores, bem como leva também sua história de vida, seu presente e seu 
projeto futuro. Não se trata de uma alma metafísica, transcendente, mas uma alma que constitui o sujeito enquanto humano que é e, portanto, corpo e alma são unos:

Que não pare, que esta chuva não pare, murmurava enquanto buscava na cozinha os sabões, os detergentes, os esfregões, tudo o que pudesse servir para limpar um pouco, ao menos um pouco, esta sujidade insuportável da alma. Do corpo, disse, como para corrigir o metafísico pensamento, depois acrescentou, É o mesmo. Então, como se só essa tivesse de ser a conclusão inevitável, a conciliação harmónica entre o que tinha dito e o que tinha pensado, despiu de golpe a bata molhada, e, nua, recebendo no corpo, umas vezes a carícia, outras vezes a vergastada da chuva, pôs-se a lavar as roupas, ao mesmo tempo que a si própria. (SARAMAGO, 1995).

Já o termo espírito, o encontramos em dois sentidos: em algumas frases seria possível substituir este termo por alma, compreendida como realçamos acima, mas em outros momentos não. Estes momentos que não encontramos espírito e alma como sinônimos, o termo espírito pode ser compreendido como similar ao termo senso. Ou seja, o espírito pode representar tanto o Eu do sujeito, como indicar um estado coletivo ou individual, uma representação simbólica ou arquetípica, um senso ético ou moral, como os exemplos a seguir: "espírito científico", "espírito lógico", "estado de espírito", "espírito de vingança”, "espírito de justiça”, "espírito observador", "espírito de honesta indignação", "espírito da disciplina", "espírito de família", "espírito de previdência", "espírito da tribo". (SARAMAGO, 1995).

Por fim, Saramago (1995) faz essa conciliação entre alma e espírito, em uma frase esclarecedora, durante um diálogo entre o médico, a rapariga dos óculos escuros e o velho da venda preta:

Ninguém fez perguntas, o médico só disse, Se eu voltar a ter olhos, olharei verdadeiramente os olhos dos outros, como se estivesse a ver-lhes a alma, A alma, perguntou o velho da venda preta, Ou o espírito, o nome pouco importa, foi então que, surpreendentemente, se tivermos em conta que se trata de pessoa que não passou por estudos adiantados, a rapariga dos óculos escuros disse, Dentro de nós há uma coisa que não tem nome, essa coisa é o que somos. (SARAMAGO, 1995).

Passando agora para o sentido de comunidade, Saramago (1995) vai deixando clara a importância do coletivo para a sobrevivência física e do espírito. Sem essa existência comunitária, há a consequente desumanização, a morte do espírito humano:

Tu, que vais fazer agora, Nada, fico aqui, à espera de que os meus pais voltem, Sozinha e cega, À cegueira já me habituei, E à solidão, Terei de habituar-me, a vizinha de baixo também vive só, Queres converter-te naquilo que ela é, alimentar-te de couves e de carne crua, enquanto durarem, nestes prédios por aqui parece não viver mais ninguém, serão duas a odiar-se com medo de que a comida se acabe, cada talo que apanharem estarão a roubá-lo à boca da outra, tu não viste essa pobre mulher, da casa só sentiste o cheiro, digo-te que nem lá onde vivemos era tão repugnante, Mais tarde ou mais cedo todos vamos ser como ela, e depois acabamos, não haverá mais vida, Por enquanto ainda vivemos, Escuta, tu sabes muito mais do que eu, ao pé de ti não passo duma ignorante, mas o que penso é que já estamos mortos, estamos cegos porque estamos mortos, ou então, se preferes que diga isto doutra maneira, estamos mortos porque estamos cegos, dá no mesmo. (SARAMAGO, 1995).

No trecho acima destacado, quando a mulher do médico fala à rapariga que nem no manicômio onde estavam internados era mais repugnante que a casa da velha do primeiro 
andar, que viva só, percebemos claramente a necessidade humana de não viver só. Assim, ao longo do texto, Saramago (1995) revela que, por mais doente que esteja uma pessoa, a condição de estar junto a um grupo é essencial para a cura dessa doença. No caso da obra em análise, a doença é representada pelo mal-branco.

Seguindo o traçado ao longo da narrativa, percebemos que inicialmente, quando se iniciou o surto de cegueira, Saramago (1995) não traça formas de união entre as personagens, no sentido de participarem de um grupo. Quando o primeiro cego foi acometido pelo mal, no meio da rua, houve um aglomerado de pessoas, todas falando, nenhuma ouvindo, organizando, unindo. O único que ofereceu ajuda foi o mesmo que o roubou. Quando o governo toma a decisão de isolar os acometidos pela cegueira, começa a criar uma visão de grupo social. Entretanto, apesar de o governo ser aquele que, em princípio iria organizar e tomar providências para unir, proteger e solucionar problemas para o bem comum, o que foi desenvolvido foi um governo autoritário, desagregador. Temos assim, a primeira pista de Saramago (1995) em relação ao ser humano comunitário: comunidade não é apenas agrupamento de pessoas regido por regras.

Foi a partir da união do grupo protagonista que essa noção de comunidade foi ganhando forma. Era um grupo de pessoas, unidos por um motivo em comum (a cegueira), compartilhando o mesmo espaço, partilhando cuidados e comida, dividindo a esperança de cura. A mulher do médico, a única que não perdeu a visão, foi o elemento principal para a coesão do grupo. À medida que as dificuldades aumentavam, ainda dentro do internato, mais unido o grupo ficava. Passaram pela partilha do alimento escasso, pela morte de companheiros, pela sujeira e pelo mau cheiro que dominou todo o ambiente, pelo estupro das mulheres, pelo enfrentamento do inimigo ("malvados"). Para conseguirem enfrentar o grupo dos "malvados", os grupos das várias camaratas se organizaram e se uniram:

\begin{abstract}
Não irão apenas os homens, irão também as mulheres, voltaremos ao lugar onde nos humilharam para que da humilhação nada fique, para que possamos libertar-nos dela da mesma maneira que cuspimos o que nos lançaram à boca. Disse e ficou à espera, até que a mulher falou, Aonde tu fores, eu irei, foi isto o que disse. O velho da venda preta sorriu, pareceu um sorriso feliz, e talvez o fosse, não é a ocasião para lho perguntar, mais interessante é reparar na expressão de estranheza dos outros cegos, como se alguma coisa lhes tivesse passado por cima das cabeças, um pássaro, uma nuvem, uma primeira e tímida luz. (SARAMAGO, 1995).
\end{abstract}

Evidenciamos, na passagem acima, elementos fundamentais para a constituição de uma comunidade, a partir de ESC: união, liberdade, lealdade. Esses sentimentos provocaram expressões que indicavam a presença de uma pequena luz sobre suas cabeças. Unidos pela coragem de enfrentamento do grupo dos "malvados", acabaram perdendo a batalha. Mas a mulher da segunda camarata da ala direita, a mesma que disse no realce acima que iria onde fosse a mulher do médico, encheu-se de coragem e tomou a decisão de enfrentar, sozinha, o mal. Foi então que ela colocou fogo na camarata onde o grupo estava, se sacrificando pelo grupo dos demais cegos, oprimidos por este.

Quando saíram do internato, a cidade estava um caos. As pessoas andavam em grupos. Isso as ajudava na sobrevivência. E como visto mais acima, não apenas a sobrevivência física, mas do espírito. Afinal, estamos considerando que a visão expressa por Saramago (1995) é de um ser humano em que físico e espírito são indissociáveis. Ressaltamos mais dois indicativos da importância dada ao espírito comunitário: o grupo que debatia, numa praça, sobre salvação, profecias, bíblia. Mais tarde, pouco antes de as pessoas recuperarem a visão, houve outro grupo reunido também em uma praça. Este grupo discutia sobre 
organização, Estado, repressão, mercado. Sobre estes dois grupos destacados, realçamos que, ao passar pelo primeiro, a mulher do médico ressaltou que eles não falavam sobre organização. Ao passar pelo segundo, ela enfatizou, novamente, a palavra organização, chamando a atenção sobre este grupo discutir formas de organização. Assim, vemos que a organização é um elemento fundamental na constituição da comunidade, a partir da leitura de ESC.

Destarte, uma sociedade ou um grupo são importantes para a sobrevivência física e espiritual do sujeito. Entretanto, o espírito de comunidade é necessário para manter a sanidade desses grupos ou sociedades. E tal como se evidenciou o pensamento saramaguiano na unidade corpo e espírito, evidenciamos também ser a dimensão social indissociável do ser humano. Entretanto, para que o ser não adoeça, é necessário que haja um sentimento de comunidade no social. O sujeito constitui o mundo e o mundo constitui o sujeito. Por isso a mulher do médico disse que também estava a cegar, uma vez que ninguém a podia ver. Troca e partilha. Compreendemos, a partir dos bosques saramaguianos, que o ser humano além de social, precisa de uma comunidade. A falta desse comum é revelado como elemento importante na reflexão sobre a causa da cegueira. Acresce-se a isso a indicação de "uma primeira e tímida luz" surgida após a união do grupo tomar forma de uma comunidade. (SARAMAGO, 1995).

Por fim, abordaremos o sentido extraído por nós acerca da cegueira branca. Em princípio, não se trata de uma cegueira comum: ela não é negra como as demais, não existem sequelas orgânicas que a justifique e é contagiosa. Fica claro, ao longo da narrativa, que a cegueira é uma doença do espírito, uma doença social, uma doença do corpo. Mas somente no avançar das páginas do romance, que encontramos, quase ao final, pouco antes de os cegos recuperarem a visão, uma grande chave dada por Saramago (1995). Estamos nos referindo ao momento em que a mulher do médico e o médico chegam à igreja. Nesse momento Saramago (1995) realça haver, ali, seis degraus: "Entrava-se no templo por seis degraus, seis degraus, nota bem”. Então, já dentro do templo, ela depara-se com as imagens e estátuas com seus olhos vendados por uma tarja branca. Exceto uma imagem, uma mulher que carregava os seus olhos em uma bandeja. Ao tomarem consciência desse fato, os cegos que ali se encontravam apavoraram-se:

o mau foi haver no ajuntamento umas quantas pessoas supersticiosas e imaginativas, a ideia de que as sagradas imagens estavam cegas, de que os seus misericordiosos ou sofredores olhares não contemplavam mais que a sua própria cegueira, tornou-se subitamente insuportável, foi o mesmo que terem vindo dizer-lhes que estavam rodeados de mortos-vivos, bastou ter-se ouvido um grito, e depois outro, e outro, logo o medo fez levantar toda a gente, o pânico empurrou-os para a porta, repetiu-se aqui o que já se sabe, como o pânico é muito mais rápido que as pernas que o têm de levar, os pés do fugitivo acabam por enrolar-se na corrida, muito mais se é cego, e ei-lo de repente no chão, o pânico diz-lhe Levanta-te, corre, que te vêm matar, bem o quisera ele, mas já outros correram e caíram também, é preciso ser-se dotado de muito bom coração para não desatar a rir diante deste grotesco emaranhado de corpos à procura de braços para libertar-se e de pés para escapar. Aqueles seis degraus lá fora vão ser como um precipício, mas, enfim, a queda não será grande, o costume de cair endurece o corpo, ter chegado ao chão, só por si, já é um alívio, Daqui não passarei, é o primeiro pensamento, e às vezes o último nos casos fatais. (SARAMAGO, 1995).

Essa passagem da igreja possui um vasto material simbólico. Iniciaremos abordando a imagem da mulher com os olhos na bandeja de prata, a qual nos remete a Santa Luzia, a protetora dos olhos, cujos devotos pedem a cura para doenças oculares, inclusive para a 
cegueira. Como se tratava da única imagem que não tinha os olhos vendados pela tarja branca, bem como trazia seus olhos como oferenda em uma bandeja, podemos relacioná-la à personagem da mulher do médico. Também ela ofereceu seus olhos aos demais, carregando "A responsabilidade de ter olhos quando os outros os perderam”. (SARAMAGO, 1995). Assim, aludindo à santa protetora dos olhos e da cura da cegueira, a personagem da mulher do médico pode ser interpretada como a protetora dos cegos e a que lhes curou.

Outro simbolismo que nos saltou na cena em análise, foi a demarcação do número seis, enfatizando que eram seis degraus para entrar no templo e, obviamente, para sair. Por que essa demarcação do número seis? Só pudemos responder a essa questão após compreendermos todo o sentido que compõe a cena. As imagens sacras com os olhos tampados representaram, aos cegos "supersticiosos" que havia ali, a queda do sagrado. A morte de Deus nietzschiana. O sagrado representado pelas imagens era a própria cegueira humana.

Completando o vestígio da representação da morte de Deus, realçamos o número seis, destacado nessa passagem e, verificamos posteriormente, número encontrado em variados momentos da obra. Diante dessa atenção ao número seis, após uma passagem que associamos com a morte de Deus, o simbolismo cristão do número vem a agregar sentido. Foi no sexto dia que se deu a criação do homem. O que isso nos revela? Em nosso entendimento, há um direcionamento de sentido ao humano. O humano que, sem o chão do sagrado que o sustentava, despencou pelos degraus terrenos da humanidade. Mas Saramago (1995) ainda destaca que, apesar de terem os cegos despencados, esse pouso no chão poderia ser um alívio.

O pavor diante da morte de Deus, o medo gerado pelo anúncio, pode ser a marca de toda a desorganização e cegueira traçadas por Saramago (1995): “O medo cega, disse a rapariga dos óculos escuros, São palavras certas, já éramos cegos no momento em que cegamos, o medo nos cegou, o medo nos fará continuar cegos". (SARAMAGO, 1995). O medo de aceitar-se humano, sem Deus, os cegou e os fez perder a alma de si e do próximo. Lembramo-nos do grupo descrito na obra que, reunido em uma praça, discutia, sobretudo, temas metafísicos como salvação, anjos, visão do sétimo dia. A mulher do médico advertiu que este grupo não falava sobre organização. Posteriormente, momentos antes da cena da igreja, a mulher do médico e o médico passam por uma praça em que um grupo de cegos discutia sistemas de organizados, mercado, finanças, governo. Então, a mulher do médico ressalta que ali sim, falavam sobre organização. Assim, além da passagem da igreja, essas cenas dos dois grupos demonstram como, enquanto ainda discutia-se sobre temas metafísicos, a cegueira permanecia. A partir do momento em que passaram a discutir temas terrenos, com destaque para a organização, chegou-se o momento da cura. Destacamos um diálogo entre o médico, sua esposa e a rapariga dos óculos escuros, acerca da organização:

O mal é não estarmos organizados, devia haver uma organização em cada prédio, em cada rua, em cada bairro, Um governo, disse a mulher, Uma organização, o corpo também é um sistema organizado, está vivo enquanto se mantém organizado, e a morte não é mais do que o efeito de uma desorganização, E como poderá uma sociedade de cegos organizar-se para que viva, Organizando-se, organizar-se já é, de uma certa maneira, começar a ter olhos, Terás razão, talvez, mas a experiência desta cegueira só nos trouxe morte e miséria, os meus olhos, tal como o teu consultório, não serviram para nada, Graças aos teus olhos é que estamos vivos, disse a rapariga dos óculos escuros, Também o estaríamos se eu fosse cega, o mundo está cheio de cegos vivos, Eu acho que vamos morrer todos, é uma questão de tempo, Morrer sempre foi uma questão de tempo, disse o médico, Mas morrer só porque se está cego, não deve haver pior maneira de morrer, Morremos de doenças, de acidentes, de acasos, E agora morreremos

https://periodicos.unifap.br/index.php/letras Macapá, v. 8, n. 3, $2^{\circ}$ sem., 2018 
também porque estamos cegos, quero dizer, morreremos de cegueira e de cancro, de cegueira e de tuberculose, de cegueira e de sida, de cegueira e de enfarte, as doenças poderão ser diferentes de pessoa para pessoa, mas o que verdadeiramente agora nos está a matar é a cegueira, Não somos imortais, não podemos escapar à morte, mas ao menos devíamos não ser cegos, disse a mulher do médico, Como, se esta cegueira é concreta e real, disse o médico, Não tenho a certeza, disse a mulher, Nem eu, disse a rapariga dos óculos escuros. (SARAMAGO, 1995).

Destarte, a organização fica evidentemente demarcada enquanto necessidade social, espiritual e física. É relacionada à própria vida. O medo, como vimos, cega. Com medo de ver a realidade que lhes apresentava à frente, cegaram. Em se tratando de algo que sustentava a sociedade, a desorganização é certa. Foi o que sucedeu na trama saramaguiana. E foi a personagem da mulher do médico quem representou o papel de ajudar os cegos a organizarem-se, ainda que cegos de si e cegos dos outros, não permitindo a desumanização e a morte destes. A partir da organização, da partilha, da união, da queda dos seis degraus e da consciência da morte de Deus, a visão foi reconquistada.

\section{Espiritualidade ateia a partir de Saramago}

Em sua obra intitulada $O$ espírito do ateísmo, o filósofo francês André Comte-Sponville (2016) afirma que o fato de não crer em Deus não significa que não haja possibilidade de se ter uma vida espiritual. Ele conclui, a partir de evidências históricas que é possível a uma sociedade viver sem religião. Entretanto, não é possível, que uma sociedade viva sem comunhão, nem fidelidade. Para o autor, a comunhão é anterior e necessária para a existência de uma comunidade. Ele retorna a Durkheim e diz que para este e para a maioria dos sociólogos, a principal função da religião é "a coesão social fortalecendo a comunhão das consciências e a adesão às regras do grupo”. (COMTE-SPONVILLE, 2016, p. 23). Ele define o termo comunhão como um compartilhamento sem divisão e afirma que este é, portanto, um ato do espírito, pois somente este é capaz de compartilhar sem, no entanto, realizar uma divisão. É isso que possibilita a criação de vínculos. Segundo o autor, não há sociedade sem vínculos e, portanto, sem comunhão.

Destarte, percebemos que a teoria sponvilliana está em sintonia com a obra saramaguiana analisada no item anterior. Percebemos, nas páginas do romance, como a criação de vínculos, a coesão dos grupos e a partilha foram fundamentais para a sobrevivência dos cegos e para a recuperação da visão. Realçamos que Comte-Sponville (2016), tal como posto por Saramago (1995), considera essas ações de compartilhamento, como ações do espírito.

O outro ponto que o autor afirma que uma sociedade não pode viver sem, a fidelidade, é compreendida por ele como aquilo que recolhe e relê. Dessa forma, acredita que não é possível haver comunhão sem fidelidade: "Não é possível recolher-se juntos (comungar), a não ser onde alguma coisa, primeiro, foi recolhida, ensinada, repetida ou relida. (...) Não há civilização sem transmissão". (COMTE-SPONVILLE, 2016, p. 28). Assim, o autor diferencia fidelidade de fé. Para ele, a fé trata-se da crença em um (ou vários) deus. Já a fidelidade trata-se de um comprometimento e reconhecimento de valores, da história, da pessoa humana, da comunidade. Comte-Sponville (2016), nesse sentido, afirma que "A primeira é do âmbito do imaginário ou da graça; a segunda, da memória e da vontade". (COMTESPONVILLE, 2016, p. 29). Nesse entendimento, um ateu não possui fé, mas pode ter um compromisso moral, ético, histórico: é o que o autor denomina de ateu fiel.

Demarcarmos, na análise do romance do escritor português, que a salvação da epidemia

https://periodicos.unifap.br/index.php/letras

Macapá, v. 8, n. 3, $2^{\circ}$ sem., 2018 
de cegueira não foi atribuída, na obra, a Deus, mas veio a partir da própria humanidade. Já vemos, então, outro elemento de consonância entre as visões saramaguiana e sponvilliana. Ao longo de toda narrativa podemos nos deparar com atos de fidelidade, de comprometimento, de afirmação da memória enquanto algo que ainda permitia aos cegos manterem-se humanos. Enfim, especialmente guiados pela mulher do médico, a protetora dos olhos, esse comprometimento com os valores e com a humanidade do ser foram buscas constantes. Inclusive, a falta desses valores relaciona-se, na obra, ao adoecimento do mal-branco. Destarte, Comte-Sponville (2016) ressalta a impossibilidade de uma sociedade sem comunidade e fidelidade. Quando isso faltou às personagens saramaguianas, a sociedade diluiu-se no caos da epidemia de cegueira.

Ao que tange a espiritualidade, ainda que sem um Deus pessoal, Comte-Sponville (2016) ressalta que, apesar de soar estranho o termo espiritualidade ateia, espiritualidade e ateísmo não são paradoxais. Ele destaca que o fato de não crer em Deus ou não ter uma religião não são impeditivos de ter um espírito e uma vida espiritual. O filósofo considera a espiritualidade enquanto dimensão humana que corresponde aos atos do espírito. Esses atos, para ele, não exigem transcendência, tampouco a existência de Deus, Deuses ou seres sobrenaturais. De acordo com Comte-Sponville (2016), a espiritualidade corresponde à abertura do ser para a realidade, diante de uma série de exigências, mas especialmente, de amor e verdade, no qual o ser é contido pelo Todo, em sua imanência. Assim, o autor demonstra que é possível dizer de uma espiritualidade ateia. Termo esse que causa estranheza na cultura ocidental, uma vez que o termo "espiritualidade" está, culturalmente, ligado à religião. Porém, ele destaca que no Oriente, essa ideia existe desde tradições milenares, a exemplo do Budismo e do Confucionismo, conforme demarcado anteriormente.

De acordo com Comte-Sponville (2016), a função mais elevada do ser humano é a espiritual. Para ele, é devido aos atos do espírito que podemos nos diferenciar dos animais não humanos e, ainda, nos tornar melhor do que somos. Dessa forma, "Não ter religião não é motivo nenhum para renunciar a toda vida espiritual". (COMTE-SPONVILLE, 2016, p. 127). Por isso, na obra saramaguiana, ao identificar a cegueira como um adoecimento do espírito, o escritor indica a desumanização e a aproximação de tornarem-se animais.

Segundo Comte-Sponville (2016), é o que podemos chamar de espiritualidade. O autor compreende o ser humano enquanto seres relativos abertos para o absoluto. Essa abertura é, para o autor, o espírito. É o que nos permite estarmos abertos à realidade. Assim, ele enfatiza:

Ser ateu não é negar a existência do absoluto; é negar a sua transcendência, a sua espiritualidade, a sua personalidade - é negar que o absoluto seja Deus. Mas não ser Deus não é ser nada! Senão, o que seríamos, e o que seria o mundo? Se se entender por 'absoluto', é o sentido corrente da palavra, o que existe independentemente de qualquer condição, de qualquer relação ou de qualquer ponto de vista - por exemplo, o conjunto de todas as condições (a natureza), de todas as relações (o universo), que também engloba todos os pontos de vista possíveis ou reais (a verdade) -, não vejo como poderíamos negar sua existência: o conjunto de todas as condições é necessariamente incondicionado, o conjunto de todas as relações é necessariamente absoluto, o conjunto de todos os pontos de vista não é um ponto de vista. (COMTESPONVILLE, 2016, p. 129-130).

Dessa forma, o filósofo explica que a espiritualidade sem Deus é naturalista, imanentista ou materialista. O autor descarta a possibilidade da transcendência espiritual, 
demarcando o caráter imanente da espiritualidade. Aqui também podemos identificar similaridade com o expresso pela narrativa de ESC. Retomamos que, ao discutirmos sobre a morte de Deus, o escritor português ressaltou valores humanos, de um espírito imanente, o que permitiu aos cegos retomarem a visão.

\section{Considerações Finais}

A Teopoética é um campo academicamente novo, mas em grande expansão. Autores de diversas áreas tem encontrado, nas interfaces entre religião e literatura, um campo investigativo profícuo. Como um objeto de arte, a literatura nos permite abrir horizontes diversos e ricos. Nossa pesquisa visou trabalhar relações entre espiritualidade ateia, no campo dos fenômenos religiosos, e a literatura de José Saramago através da obra ESC. Portanto, trata-se de uma pesquisa em teopoética.

A partir da análise realizada da obra saramaguiana, é possível perceber o universo simbólico expresso pela narrativa. O que traçamos aqui é um pequeno recorte deste universo. Entretanto, consideramos elementos fundamentais para a compreensão do sentido da obra como um todo. Saramago (1995) nos propõe a responsabilidade, unicamente humana, de mantermos os olhos sãos diante do adoecimento social. Demarca a importância do espírito, da fidelidade e da comunidade para que o ser humano se sustente como tal. Por fim, encontramos grande ressonância entre o romance abordado e a espiritualidade ateia de Comte-Sponville (2016). O que traçamos neste artigo é apenas o princípio do caminho de um vasto bosque a ser percorrido.

\section{Referências}

CANTARELA, Antônio Geraldo. A pesquisa em teopoética no Brasil: pesquisadores e produção bibliográfica. Horizonte: revista de estudos de Teologia e Ciências da Religião da Pontifícia Universidade Católica de Minas Gerais, Belo Horizonte, v. 12, n. 36, p. 1228-1251, out./dez. 2014. Disponível em: < http://periodicos.pucminas.br/index.php/horizonte/article/view/P.2175-5841.2014v12n36p1228/7526>. Acesso em 17 mar. 2018.

COMTE-SPONVILLE, André. O espírito do ateísmo. 2. ed. São Paulo: WMF Martins Fontes, 2016.

LOPES, Márcio Cappelli Aló. Por uma Teologia ficcional: a (des)construção teológica na reescritura bíblica de José Saramago. 2017. 326 f. Tese (Doutorado) - Pontifícia Universidade Católica do Rio de Janeiro, Programa de pós-graduação em Teologia, Rio de Janeiro, 2017.

MANZATTO, Antônio. Teologia e Literatura: reflexão teológica a partir da antropologia contida nos romances de Jorge Amado. São Paulo: Loyola, 1994.

MANZATTO, Antônio. Em torno da questão da verdade. Horizonte: revista de estudos de Teologia e Ciências da Religião da Pontifícia Universidade Católica de Minas Gerais, Belo Horizonte, v. 10, n. 25, p. 12-28, jan./mar. 2012a. Disponível em: < http://periodicos.pucminas.br/index.php/horizonte/article/view/P.2175-

5841.2012v10n25p12/3552>. Acesso em 26 dez. 2017.

MANZATTO, Antônio. Literatura e Teologia da Libertação. Teoliterária: Revista de Literaturas e Teologias da Pontifícia Universidade Católica de São Paulo, São Paulo, 


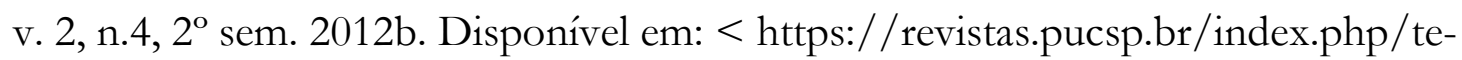
oliteraria/article/view/22902>. Acesso em: 23 dez. 2017.

MANZATTO, Antônio. Teologia e Literatura: bases para um diálogo. Interações: Cultura e Comunidade da Pontifícia Universidade Católica de Minas Gerais, Belo Horizonte, v.11, n.19, p.8-18 , Jan./Jun. 2016. Disponível em: <http://periodicos.pucminas.br/index.php/interacoes/article/view/P.1983-2478.2016v11n19 p8>. Acesso em: 26 dez. 2017.

SARAMAGO, José. Ensaio sobre a cegueira. São Paulo: Companhia das Letras, 1995. [versão Kindle]. Retirado de http://www.amazon.com/. 